\title{
Formulation of gluten-free cupcake with hydrocolloids for people with Celiac disease
}

\author{
Carolina Gómez, Jhoana Colina
}

Department of Biological and Biochemical Process Technology of Simon Bolivar University, Caracas, Venezuela, 1010-A.

Corresponding Author: Carolina Gomez, Department of Biological and Biochemical Process Technology of Simon Bolivar University, Caracas, Venezuela, 1010-A.

Submission Date: September $17^{\text {th }}$, 2018. Acceptance Date: June $28^{\text {th }}$, 2019. Publication Date: June $30^{\text {th }}, 2019$.

Citation: Gomez C., Colina J. Formulation of gluten-free cupcake with hydrocolloids for people with Celiac disease. Bioactive Compounds in Health and Disease 2019; 2(6): 134-148.

https://doi.org/10.31989/bchd.v2i6.630

\begin{abstract}
Background: The development of gluten-free products is a great challenge for manufactures aiming to make baked products have a similar composition to their gluten-containing counterparts. They routinely use commercial and vegetable additives (rice flour and cassava starch), which are gluten free. Due to the fact that most of these products in Venezuela are imported and thus expensive, the prominence of celiac disease increases by $4 \%$ every year. This work aimed to develop a filled cupcake formulation with the use of natural and synthetic gluten-free hydrocolloids for those with celiac disease.
\end{abstract}

Methods: Two mixture designs, one with rice flour and one with cassava flour, were examined to identify which flour would give the cupcake the best consistency. The flours were mixed with hydroxypropyl methylcellulose (HPMC) and vegetable fat (emulsifier) to see which proportion of ingredients was best-suited for the final product. The response variables of adhesiveness, cohesiveness, hardness, and gumminess were used to develop a texture profile. Two formulations were then obtained based on desirability ratings, and then evaluated based on the acceptability of 50 celiac patients. The physical, chemical and microbiological characterization, along with the storage stability of the selected formulation, was evaluated. The shelf life of the cupcake was determined by evaluating the texture profile, acceptability and microbiological parameters during 21 days at three temperatures $\left(25^{\circ} \mathrm{C}, 35^{\circ} \mathrm{C}\right.$ and $\left.45^{\circ} \mathrm{C}\right)$.

Results: The formulation with the greatest desirability in our population had the lowest gliadin content $(0.231 \mathrm{ppm})$, the lowest production cost, and showed a decrease in acceptability as time and temperature increased. The shelf life of the cupcakes was estimated to be 14 days when stored at an average temperature of $28^{\circ} \mathrm{C}$. 
Conclusion: Our study demonstrates that it possible to produce a low-cost, high-calorie filled cupcake for people with celiac disease to consume.

Keywords: Hydrocolloids, gluten-free filled cup cake, gluten, compound flours, celiac disease

\section{BACKGROUND}

The close relationship between health and nutrition has been well-documented. As a result, the composition of many food products has been modified by reducing, eliminating, or adding certain nutrients in order to prevent health deficiencies and excesses [1].

Those with physical or physiological conditions and diseases have special dietary needs, in which specific foods are required to meet these needs. The composition of these foods must be different from the standard products that are used by the majority of people. [2]. One given condition is celiac disease (CD), an autoimmune disease characterized by inflammation and atrophy of the villi of the small intestine, resulting in malabsorption of vitamins and nutrients. It is caused by an immune response to gluten (wheat protein). CD commonly causes chronic diarrhea, steatorrhea, poor absorption and, growth retardation in childhood [3].

Gluten is a major protein and is presents in all foods that contain wheat, rye, barley and oats. Gluten accounts for $90 \%$ of the protein in these cereals. Proteins are divided based on their solubility in water. The insoluble fraction of gluten is the principal section, and it is subdivided into two components: glutelins and prolamins [4]. The percentage of protein and prolamins in each cereal grain varies, as does the name of the prolamin in each grain. (Table 1).

Table 1. Content of proteins and prolamins in cereal grains

\begin{tabular}{cccc}
\hline Cereal & Prolamin & Protein (\%) & Prolamins (\%) \\
\hline Wheat & Gliadin & $10-15$ & $4.7-7.5$ \\
Rye & Secaline & $9-14$ & $3.0-7.0$ \\
Barley & Hordeine & $10-14$ & $3.5-7.0$ \\
Oats & Avenin & $8-14$ & $0.8-2.1$ \\
\hline
\end{tabular}

The replacement of gluten in baked products is one of the great challenges for those working in food science. Patients with celiac disease, or gluten-sensitive enteropathy (GSE), must adhere to a gluten-free diet for life. To make quality gluten-free products, hydrocolloids are used due to their ability to change the rheological properties of the product, thus improving its texture [5].

A range of gluten-free bread (GFB) formulations have been developed using rice and maize flours. These flours are often combined with maize, potato, or cassava starches because they are widely available, inexpensive and bland in taste and flavor.

In Venezuela, these specialized products are generally imported and of high cost because their availability depends on several external factors: import procedures, currency settlement, availability of resources, nationalization of the product, marketing permits, among others. In addition, there is a limited variety of these products because the market is small, manufacturers are scarce and there is little competition [6]. Therefore, this research was conducted to develop a filled cupcake formulation with the use of natural and synthetic gluten-free hydrocolloids for those with celiac disease. 


\section{METHODS}

\section{Selection of ingredients}

A homemade recipe of a normal cupcake was selected to determine the ingredients. The glutenfree hydrocolloid ingredients, HPMC, CMC, Monopals and, Xanthan, were substituted for the wheat flour. These ingredients were intended to improve the texture of the product. The recipe selected to make the cupcake is shown in table 2.

Table 2. Original recipe used to develop the filled gluten-free cupcake and the proportions of each ingredient

\begin{tabular}{cc}
\hline Ingredients & Proportion (\%) \\
\hline Sugar & 18.35 \\
Wheat Flour & 30.27 \\
Baking Powder & 0.30 \\
Milk Powder & 0.13 \\
Salt & 0.13 \\
Eggs & 32.01 \\
Water & 17.93 \\
\hline
\end{tabular}

\section{Preliminary tests}

Due to the variety of hydrocolloids in the market, preliminary tests were done to examine which ones worked best. The limits of each hydrocolloid were set by their respective suppliers (Table 3).

Table 3. Limit of hydrocolloids used.

\begin{tabular}{cccc}
\hline Type of Hydrocolloid & $\begin{array}{c}\text { Maximum Concentration } \\
(\boldsymbol{\%})\end{array}$ & $\begin{array}{c}\text { Medium Concentration } \\
(\boldsymbol{\%})\end{array}$ & $\begin{array}{c}\text { Minimum } \\
\text { Concentration (\%) }\end{array}$ \\
\hline HPMC (Ashland) & 2.00 & 1.25 & 0.50 \\
MONOPALS & 2.50 & 1.75 & 1.00 \\
$\quad \begin{array}{c}\text { (Plasgaard) } \\
\text { Xanthan (CP kelco } \\
\text { keltrol) }\end{array}$ & 1.00 & 0.55 & 0.10 \\
CMC & 1.50 & 1.12 & 0.75 \\
\hline
\end{tabular}

Once the hydrocolloids were obtained, two D-optimal mix designs were made. The first design had a $27 \%$ variation of the formulation, and contained the following ingredients: cassava flour, HPMC and Monopals (Table 4). The second design, with a variation of 30\%, had the following ingredients: rice flour, HPMC and Monopals (Table 5). Subsequently, 18 formulations were obtained for each of the designs. The response variables, hardness, adhesiveness, cohesiveness and gumminess, were determined with the use of a texturometer (TA.XTplus, Stable Micro Systems). A texture profile analysis (TPA) was established by the standard method $\mathrm{N}^{\circ}$ 74-09 [7]. This test reports the force used to compress the product by $25 \%$ of its height and the force required to maintain compression for $60 \mathrm{~s}$ [8]. 
Table 4. D-Optimal design of hydrocolloids with a variation of $27 \%$ of the formulation.

\begin{tabular}{cccc}
\hline Formulation & $\begin{array}{c}\text { Proportion } \\
\mathbf{X}_{\mathbf{1}} \text { : Cassava Flour }\end{array}$ & $\begin{array}{c}\text { Proportion } \\
\mathbf{X}_{2}: \text { HPMC }\end{array}$ & $\begin{array}{c}\text { Proportion } \\
\mathbf{X}_{3} \text { : Monopals }\end{array}$ \\
\hline 1 & 24.370 & 1.261 & 1.370 \\
2 & 23.994 & 1.006 & 2.000 \\
3 & 24.328 & 1.900 & 0.772 \\
4 & 24.974 & 1.526 & 0.500 \\
5 & 23.994 & 1.006 & 2.000 \\
6 & 23.931 & 1.784 & 1.284 \\
7 & 23.780 & 1.808 & 1.411 \\
8 & 23.617 & 2.255 & 1.128 \\
9 & 23.154 & 2.500 & 1.346 \\
10 & 23.125 & 1.885 & 1.990 \\
11 & 22.500 & 2.500 & 2.000 \\
12 & 23.824 & 2.500 & 0.676 \\
13 & 23.931 & 1.784 & 1.284 \\
14 & 24.974 & 1.526 & 0.500 \\
15 & 25.000 & 1.006 & 0.994 \\
16 & 25.000 & 1.006 & 0.994 \\
17 & 23.931 & 1.784 & 1.284 \\
18 & 22.500 & 2.500 & 2.000 \\
\hline
\end{tabular}

Table 5. D-Optimal design of hydrocolloids with a variation of $30 \%$ of the formulation.

\begin{tabular}{cccc}
\hline Formulation & $\begin{array}{c}\text { Proportion } \\
\mathbf{X}_{\mathbf{1}} \text { : Rice Flour }\end{array}$ & $\begin{array}{c}\text { Proportion } \\
\mathbf{X}_{\mathbf{2}} \text { : HPMC }\end{array}$ & $\begin{array}{c}\text { Proportion } \\
\mathbf{X}_{\mathbf{3}} \text { : Monopals }\end{array}$ \\
\hline 1 & 27.894 & 1.023 & 1.083 \\
2 & 26.000 & 1.996 & 2.004 \\
3 & 27.501 & 0.500 & 1.999 \\
4 & 27.069 & 1.216 & 1.716 \\
5 & 26.447 & 2.000 & 1.553 \\
6 & 27.501 & 0.500 & 1.999 \\
7 & 26.943 & 2.000 & 1.057 \\
8 & 26.943 & 2.000 & 1.057 \\
9 & 27.245 & 1.243 & 1.513 \\
10 & 26.602 & 1.514 & 1.885 \\
11 & 27.069 & 1.216 & 1.716 \\
12 & 26.000 & 1.996 & 2.004 \\
13 & 28.500 & 0.500 & 1.000 \\
14 & 27.069 & 1.216 & 1.716 \\
15 & 26.473 & 1.027 & 2.500 \\
16 & 27.989 & 0.500 & 1.511 \\
17 & 28.500 & 0.500 & 1.000 \\
18 & 26.000 & 1.511 & 2.489 \\
\hline
\end{tabular}

\section{Optimization of the formula}

Finally, an optimization of the formulation was done using the function of desirability. This was found using the values of the response variables for a wheat-flour cupcake (control). Using this function, the two formulations were sensory characterized. 
Table 6. Optimization for the criteria design.

\begin{tabular}{cccc}
\hline \multirow{2}{*}{ Response Variable } & Desirability Function & Minimum & Criterion \\
& & $779.32 \pm 4.56$ & Maximum \\
\hline Hardness $(\mathrm{kg})$ & Optimum & $1.09 \pm 0.60$ & $779.32 \pm 4.56$ \\
Cohesiveness & Optimum & $8.19 \pm 2.31$ & $1.14 \pm 0.22$ \\
Gumminess & Optimum & $14.67 \pm 2.23$ & $14.67 \pm 1.23$ \\
Adhesiveness & Optimum & & $20.22 \pm 4.56$ \\
\hline
\end{tabular}

\section{Quantitative verification of the presence of gluten}

The presence of gluten was determined using the immunoenzymatic sandwich assay (ELISA) to quantitively analyze the prolamins of wheat (gliadin), rye (secalin) and barley (hordein) in foods declared free of gluten. This was done using the Diagnostic Automaiton, Inc. (DAI) Gliadin / Gluten ELISA kit. This method is based on the detection of proteins by the antigen-antibody reaction. The amount of color is proportional to the number of projects in the sample, which was measured by a microplate spectrophotometer (TECAN).

\section{Sensory characterization for the selection of the formula}

The acceptability was tested by a panel of 50 people, all of whom had celiac disease or a related condition. In addition, the statistical analysis Check All That Apply (CATA) was performed in order to obtain descriptors of the gluten-free cupcakes.

\section{Determination of stability during storage}

The stability during storage of a food product helps to determine the product's shelf life, the time a product can be stored before being consumed. The microbiological parameters of molds and yeasts were measured in the cupcakes and compared to the Venezuelan standard [9]. In addition, the TPA, as previously described, was calculated. A value of acceptability was also obtained through the use of a structured hedonic scale of nine points $(9=\mathrm{I}$ like very much, $5=\mathrm{I}$ am indifferent and 1 = I dislike a lot). The stability during storage was performed for a period of 21 days, and the product was stored at three different temperatures $\left(25 \pm 2,35 \pm 2\right.$ and $\left.45 \pm 2{ }^{\circ} \mathrm{C}\right)$.

\section{Statistical analysis}

The validity of the variance analysis was performed for each response variable of the D-optimal mixing design. Three assumptions were verified for each response variable: normality, constant variance and residency independence. Once each assumption was verified, the significance of the model was in turn verified and not adjusted any further.

\section{RESULTS AND DISCUSSIONS}

\section{Selection of ingredients}

After choosing the recipe, preliminary tests were performed to select the optimal gluten-free ingredients. The baking height and specific volume (SV) of the formulations were evaluated. A high specific volume is desired, because with such there are more interactions between the molecules of the product, thus improving its texture quality [10]. 
As shown in Table 7, the products made with HPMC and monopals were taller and had greater specific volumes in comparison to the products made with CMC and Xanthan. As a result, the hydrocolloids HPMC and monopals were selected to makeup the mix design in addition to the natural hydrocolloids of rice and cassava flour.

Table 7. Baking height and specific volume for each hydrocolloid.

\begin{tabular}{ccccccc}
\hline \multirow{2}{*}{ Hydrocolloid } & \multicolumn{3}{c}{ Baking height (mm) } & \multicolumn{3}{c}{ Specific Volume (SV) } \\
& $\begin{array}{c}\text { Lower } \\
\text { Limit }\end{array}$ & $\begin{array}{c}\text { Intermediate } \\
\text { Limit }\end{array}$ & $\begin{array}{c}\text { Upper } \\
\text { Limit }\end{array}$ & Lower Limit & $\begin{array}{c}\text { Intermediate } \\
\text { Limit }\end{array}$ & $\begin{array}{c}\text { Upper } \\
\text { Limit }\end{array}$ \\
\hline HPMC & $21 \pm 0.08$ & $26 \pm 0.08$ & $29 \pm 0.05$ & $7.23 \pm 0.13$ & $7.89 \pm 0.07$ & $9.12 \pm 0.04$ \\
Monopals & $20 \pm 0.12$ & $22 \pm 0.16$ & $33 \pm 0.08$ & $7.62 \pm 0.02$ & $7.92 \pm 0.06$ & $9.34 \pm 0.09$ \\
CMC & $10 \pm 0.60$ & $13 \pm 0.12$ & $19 \pm 0.12$ & $6.55 \pm 0.19$ & $7.01 \pm 0.05$ & $7.85 \pm 0.05$ \\
Xanthan & $10 \pm 0.19$ & $13 \pm 0.08$ & $20 \pm 0.18$ & $6.01 \pm 0.08$ & $7.15 \pm 0.06$ & $7.90 \pm 0.08$ \\
\hline
\end{tabular}

\section{Mix design with rice flour}

Table 11 exhibits the texture profile values of each response variable for the rice flour formulations.

Table 8. Response variables of D-optimal mixture design with $30 \%$ variation of the formulation.

\begin{tabular}{cccccccc}
\hline \multicolumn{5}{c}{ Proportion of components } & & \multicolumn{5}{c}{ Response variable } \\
Formulation & $\mathbf{X}_{\mathbf{1}}$ :Rice Flour & $\begin{array}{c}\mathbf{X}_{\mathbf{2}} \text { : } \\
\text { HPMC }\end{array}$ & $\mathbf{X}_{\mathbf{3}}$ :Monopals & Hardness(g) & Cohesiveness(g) & Gumminess & Adhesiveness \\
\hline 1 & 27.894 & 1.023 & 1.083 & 904.072 & 1.000 & $1,486.191$ & 20.897 \\
2 & 26.000 & 1.996 & 2.004 & 993.653 & 1.670 & $1,642.840$ & 4.348 \\
3 & 27.501 & 0.500 & 1.999 & 869.799 & 1.300 & $1,131.623$ & 23.782 \\
4 & 27.069 & 1.216 & 1.716 & 655.990 & 1.322 & 867.390 & 11.250 \\
5 & 26.447 & 2.000 & 1.553 & 495.999 & 1.293 & 639.633 & 24.487 \\
6 & 27.501 & 0.500 & 1.999 & 869.799 & 1.300 & $1,131.623$ & 23.782 \\
7 & 26.943 & 2.000 & 1.057 & 448.809 & 1.316 & 590.819 & 66.153 \\
8 & 26.943 & 2.000 & 1.057 & 448.809 & 1.316 & 590.819 & 66.153 \\
9 & 27.245 & 1.243 & 1.513 & 698.469 & 1.380 & $1,082.943$ & 3.573 \\
10 & 26.602 & 1.514 & 1.885 & 817.663 & 1.230 & $1,005.516$ & 25.700 \\
11 & 27.069 & 1.216 & 1.716 & 934.014 & 1.674 & $1,543.532$ & 2.495 \\
12 & 26.000 & 1.996 & 2.004 & 993.653 & 1.670 & $1,642.840$ & 4.348 \\
13 & 28.500 & 0.500 & 1.000 & 497.661 & 1.053 & 524.028 & 55.943 \\
14 & 27.069 & 1.216 & 1.716 & 934.014 & 1.674 & $1,543.532$ & 2.495 \\
15 & 26.473 & 1.027 & 2.500 & 760.349 & 1.562 & $1,124.562$ & 2.980 \\
16 & 27.989 & 0.500 & 1.511 & $1,011.463$ & 1.410 & $1,480.607$ & 2.408 \\
17 & 28.500 & 0.500 & 1.000 & 497.661 & 1.053 & 524.028 & 55.943 \\
18 & 26.000 & 1.511 & 2.489 & 918.663 & 1.230 & $1,105.516$ & 15.700 \\
\hline
\end{tabular}

\section{Formula optimization}

The desirability function suggested three formulas, from which two within the optimum design area were selected. The contour of the optimization zones is show in Figure 1. 
Table 9. Proportions of ingredients according to desirability.

\begin{tabular}{ccccc}
\hline Rice Flour & HPMC & Monopals & desirability & Sample \\
\hline 27.018 & 0.622 & 2.360 & $\mathbf{0 . 8 1 2 1}$ & $\mathbf{1}$ \\
28.295 & 0.500 & 1.205 & $\mathbf{0 . 6 5 2 0}$ & $\mathbf{2}$ \\
\hline
\end{tabular}
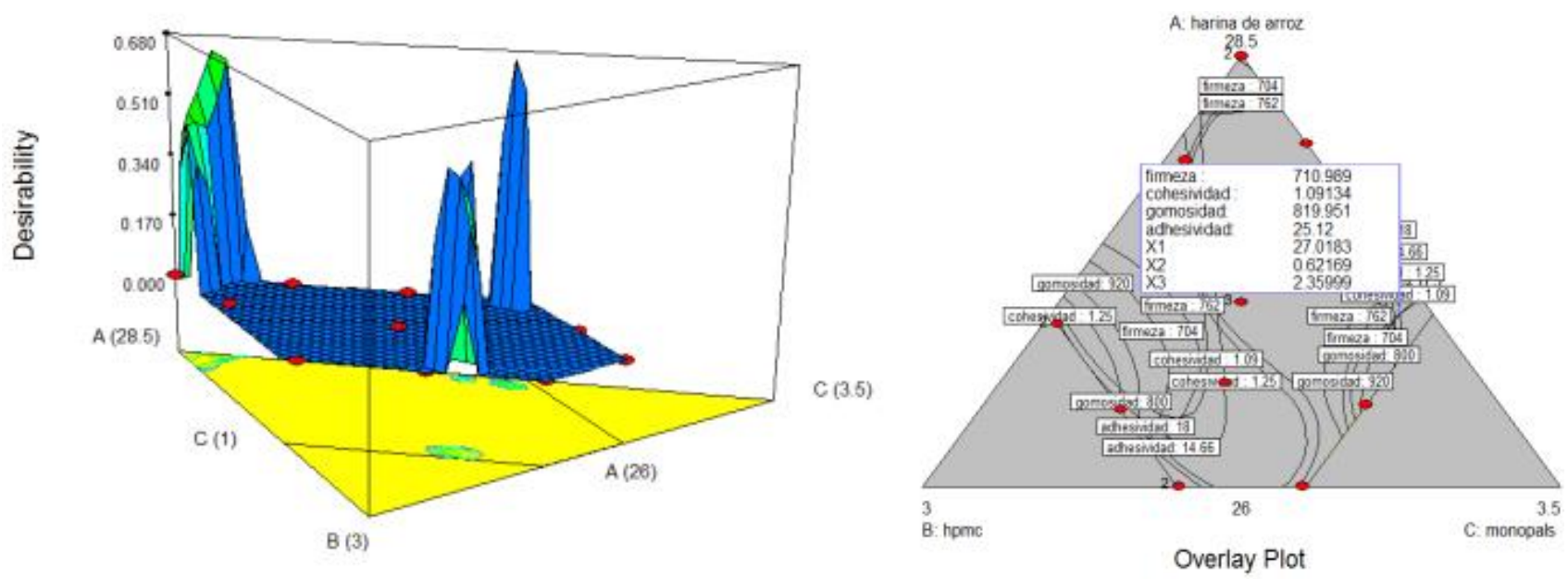

Figure 1. Contour plot of the desirability function obtained under the mix design optimization criteria

\section{Mix design for cassava starch}

Table 10 shows the texture profile values of each response variable for the cassava starch formulations.

Table 10. Response variables of D-optimal mixture design with $27 \%$ variation of the formulation.

\begin{tabular}{|c|c|c|c|c|c|c|c|}
\hline \multicolumn{5}{|c|}{ Proportion of components } & \multicolumn{3}{|c|}{ Response variable } \\
\hline Formulation & $\mathrm{X}_{1}$ : Cassava starch & $\begin{array}{c}X_{2}: \\
\text { HPMC }\end{array}$ & $\mathrm{X}_{3}$ :Monopals & Hardness(g) & $\begin{array}{c}\text { Cohesiveness( } \\
\text { g) }\end{array}$ & Gumminess & Adhesiveness \\
\hline 1 & 27.894 & 1.023 & 1.083 & 904.072 & 1.000 & $1,486.191$ & 20.897 \\
\hline 2 & 26.000 & 1.996 & 2.004 & 993.653 & 1.670 & $1,642.840$ & 4.348 \\
\hline 3 & 27.501 & 0.500 & 1.999 & 869.799 & 1.300 & $1,131.623$ & 23.782 \\
\hline 4 & 27.069 & 1.216 & 1.716 & 655.990 & 1.322 & 867.390 & 11.250 \\
\hline 5 & 26.447 & 2.000 & 1.553 & 495.999 & 1.293 & 639.633 & 24.487 \\
\hline 6 & 27.501 & 0.500 & 1.999 & 869.799 & 1.300 & $1,131.623$ & 23.782 \\
\hline 7 & 26.943 & 2.000 & 1.057 & 448.809 & 1.316 & 590.819 & 66.153 \\
\hline 8 & 26.943 & 2.000 & 1.057 & 448.809 & 1.316 & 590.819 & 66.153 \\
\hline 9 & 27.245 & 1.243 & 1.513 & 698.469 & 1.380 & $1,082.943$ & 3.573 \\
\hline 10 & 26.602 & 1.514 & 1.885 & 817.663 & 1.230 & $1,005.516$ & 25.700 \\
\hline 11 & 27.069 & 1.216 & 1.716 & 934.014 & 1.674 & $1,543.532$ & 2.495 \\
\hline 12 & 26.000 & 1.996 & 2.004 & 993.653 & 1.670 & $1,642.840$ & 4.348 \\
\hline 13 & 28.500 & 0.500 & 1.000 & 497.661 & 1.053 & 524.028 & 55.943 \\
\hline 14 & 27.069 & 1.216 & 1.716 & 934.014 & 1.674 & $1,543.532$ & 2.495 \\
\hline 15 & 26.473 & 1.027 & 2.500 & 760.349 & 1.562 & $1,124.562$ & 2.980 \\
\hline 16 & 27.989 & 0.500 & 1.511 & $1,011.463$ & 1.410 & $1,480.607$ & 2.408 \\
\hline 17 & 28.500 & 0.500 & 1.000 & 497.661 & 1.053 & 524.028 & 55.943 \\
\hline 18 & 26.000 & 1.511 & 2.489 & 918.663 & 1.230 & $1,105.516$ & 15.700 \\
\hline
\end{tabular}


The hardness values of the cassava flour formulations were significantly higher than those of rice flour. This increased hardness results in an undesired texture of the cupcakes.

The higher values of hardness in cassava flour can be attributed to the retrogradation of the starch. The polysaccharide is composed of amylose and amylopectin, in which the latter's structure changes when it is saturated by water molecules. The amylopectin transitions from an amorphous state to a vitreous one, causing the progressive increase of hardness in the cupcakes [11]. Excessive hardness and gumminess can also be caused by the elastic properties of the hydrocolloids. The texture of the product can vary when mixed with starches from different sources. Based on the given information, the rice flour formulations were selected.

\section{Determination of acceptability}

As previously stated, the acceptability of a regular (gluten-containing) cupcake was compared to that of the two gluten-free formulations using a hedonic scale of 9 points. The acceptability was rated by 50 people with celiac disease or a related condition.

The acceptability values can be seen in Table 11. It is notable that while formulation 1 had a higher acceptability value than formulation 2, the difference was not statistically significant $(p>0.05)$. Since the acceptability values were similar, the selection of a final formulation will depend on other factors. It is also notable that both of the gluten-free formulations had a lower acceptability value than that of the cupcake with gluten.

Table 11. Acceptability values of gluten-free formulations and control cupcake

\begin{tabular}{cc}
\hline Formulation & Aceptability \\
\hline 1 & $7.4 \pm 1.9_{\mathrm{a}}$ \\
2 & $7.1 \pm 1.8_{\mathrm{a}}$ \\
Cupcake with gluten (control) & $8.8 \pm 0.4_{\mathrm{b}}$ \\
\hline
\end{tabular}

Mean \pm standard deviation, $\mathrm{n}=50$.

Values with the same letter in the columns are not significantly different $(\mathrm{p}>0.05)$.

\section{Descriptors obtained through the analysis of CATA}

A Factorial Correspondence Analysis (FCA) was performed to examine the relationships among the descriptors found through CATA (Figure 2). The gluten-free formulations are located to the left of the F1 coordinate, while the control formulation is located to the right of it. In comparing the two gluten-free formulations, formulation 2 was associated with more flavor descriptors than formulation 1. Regarding texture, though, formulation 1 was more closely associated to being spongy, which is an admirable characteristic in baked products. 


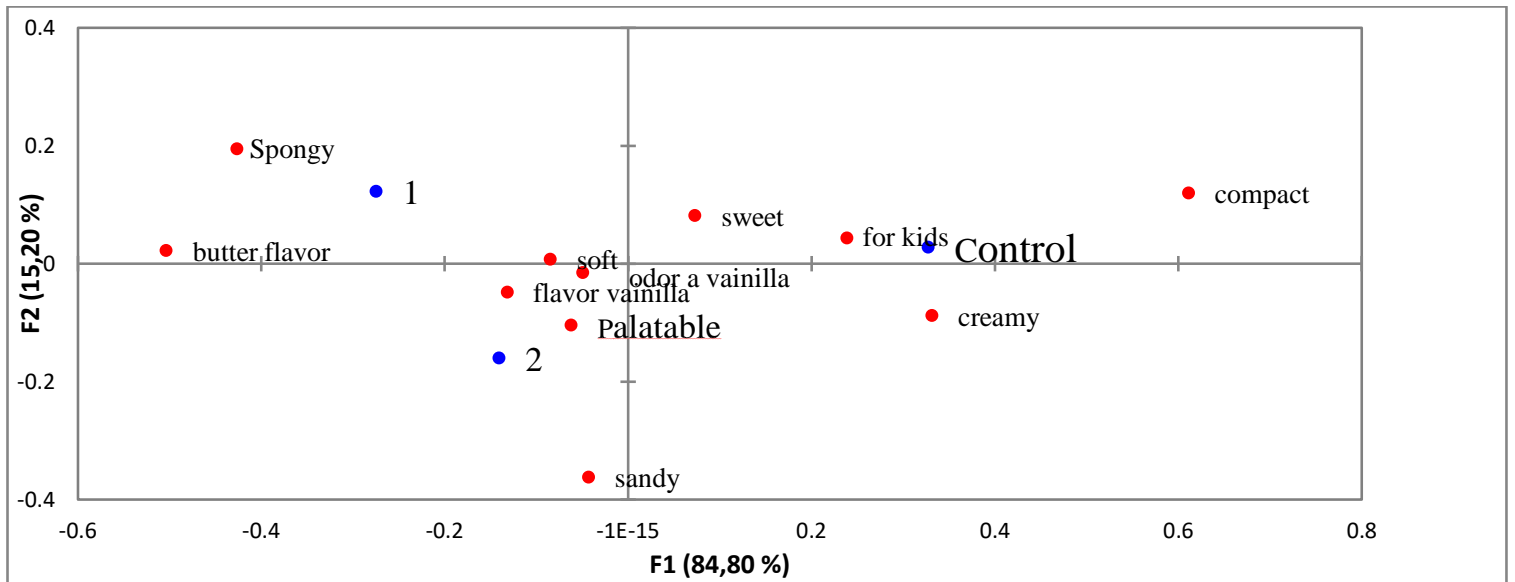

Figure 3. Factorial correspondence analysis of CATA.

\section{Determination of gluten}

The only treatment for those with celiac disease is to strictly adhere to a gluten-free diet, abstaining from wheat, oats, rye and barley. Hence why it is so important to find gluten-free foods that not only taste good but have nutritional value as well. Those with celiac disease cannot consume any food that has been contaminated with gluten at any point in time from its origin to its final commercialization [13].

The gliadin and gluten concentrations of both cupcake formulations can be seen in Table 11. According to the results obtained by the ELISA sandwich enzyme-immunoassay method, both formulations contain less than 20 ppm gluten. As a result, they can be labeled as being "glutenfree," as established in the Codex Alimentarius. As long as there is no cross-contamination in the preparation of the cupcakes, they are suitable for the consumption of people with celiac disease.

Table 12. Gluten content for samples of filled cupcakes.

\begin{tabular}{ccc}
\hline Formulation & $\begin{array}{c}\text { Gliadin Concentration } \\
(\mathbf{p p m})\end{array}$ & $\begin{array}{c}\text { Gluten Concentration } \\
(\mathbf{p p m})\end{array}$ \\
\hline 1 & $0.23 \pm 0.01$ & $<5^{*}$ \\
2 & $0.25 \pm 0.01$ & $<5^{*}$ \\
\hline
\end{tabular}

Mean \pm standard deviation, $\mathrm{n}=3$.

\section{Selection of the formulation}

After reviewing the above information, formulation 1 was selected for a variety of reasons. These included having a desirability rating close to 1 (0.81), being described as spongy, and having a lower production cost than formulation 2.

\section{Product stability}

\section{Microbiological parameters during stability storage}

The quantification of molds and yeasts in food is very important, as it can be used to indicate adequate or inadequate sanitary practices during the production and storage of products. It can also be used to examine the quality of raw materials. 
The microbiological parameters, mold and yeast, of the filled cupcakes can be seen in Table 13. For the first three weeks of the study, there was less than $10 \mathrm{cfu} / \mathrm{g}$ of molds at $25^{\circ} \mathrm{C}$ and 45 ${ }^{\circ} \mathrm{C}$. In the first two weeks of the study, there was less than $10 \mathrm{cfu} / \mathrm{g}$ of yeasts at all three temperatures $\left(25^{\circ} \mathrm{C}, 35^{\circ} \mathrm{C}, 45^{\circ} \mathrm{C}\right)$. These results are within the parameters established by the Venezuelan standard. It is notable that until the third week, the mold and yeast counts were low, inferring that good hygienic and sanitary methods were used in the preparation of the mixture. After 21 days of storage at $25^{\circ} \mathrm{C}$ though, an increase in yeast was observed. This can be attributed to the fact that this temperature, in addition to a decrease in $\mathrm{pH}$, generated optimal conditions for yeast growth [14].

Table 13. Microbiological parameters measured during the stability of filled cupcakes.

\begin{tabular}{|c|c|c|c|}
\hline \multicolumn{4}{|c|}{ Molds (cfu/g) } \\
\hline Time (days) & $25^{\circ} \mathrm{C}$ & $35^{\circ} \mathrm{C}$ & $45^{\circ} \mathrm{C}$ \\
\hline 0 & $<10^{*}$ & $<10^{*}$ & $<10^{*}$ \\
\hline 7 & $<10^{*}$ & $<10^{*}$ & $<10^{*}$ \\
\hline 14 & $<10^{*}$ & $<10^{*}$ & $<10^{*}$ \\
\hline 21 & $<10^{*}$ & $2.6 \times 10^{2}$ & $<10^{*}$ \\
\hline \multicolumn{4}{|c|}{ Yeast (cfu/g) } \\
\hline Time (days) & $25^{\circ} \mathrm{C}$ & $35^{\circ} \mathbf{C}$ & $45^{\circ} \mathrm{C}$ \\
\hline 0 & $<10^{*}$ & $<10^{*}$ & $<10^{*}$ \\
\hline 7 & $<10^{*}$ & $<10^{*}$ & $<10^{*}$ \\
\hline 14 & $<10^{*}$ & $<10^{*}$ & $<10^{*}$ \\
\hline 21 & $1.3 \times 10^{2}$ & $<10^{*}$ & $<10 *$ \\
\hline
\end{tabular}

\section{Texture Profile Analysis (TPA) during storage}

Hardness during storage.

The hardness of a product, measured by a texturometer, is defined as the peak force that is achieved during the first compression cycle. In other words, it is the resistance that prevents a permanent deformation. The phenomenon of hardness in cupcakes has scarcely been studied, but it is known that the complex interaction between multiple ingredients affects the texture of the final product [15]. The hardness of the filled cupcakes can be observed in Figure 3.

As time went on, an increase in hardness was observed. However, this increase was more evident at $35{ }^{\circ} \mathrm{C}$ and $45{ }^{\circ} \mathrm{C}$. This can be attributed to the process of food deterioration known as staling. In this process, the moisture of the cupcake is re-distributed, giving it a hard and smooth consistency. This process is favored at high temperatures, which explains the results of the cupcakes examined [16]. 


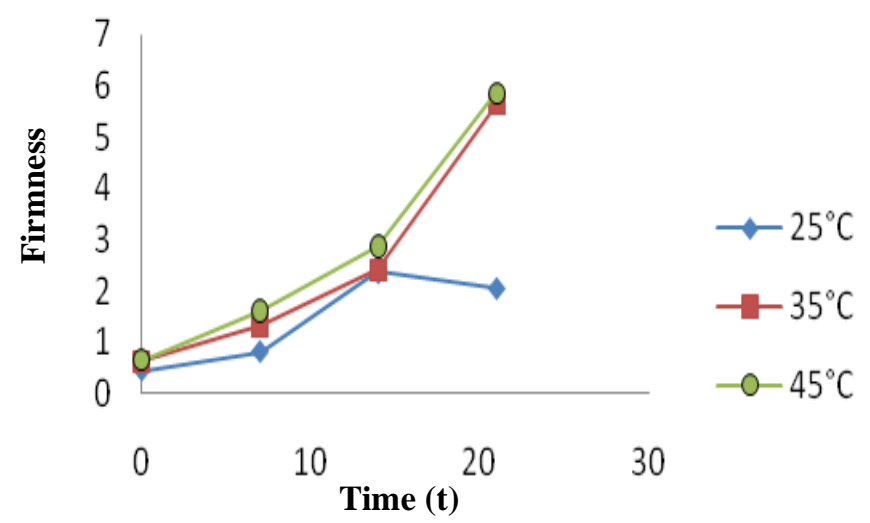

Figure 3. Variation of hardness as a function of time and temperature.

\section{Cohesiveness during storage}

Cohesiveness is the mechanical property of texture that indicates how well the form of particles is maintained after force is applied. It is due to the nature and concentration of the material in the intercellular spaces of a product [17]. The cohesiveness of a food represents the magnitude of deformation after being broken by the application of force.

As seen in Figure 4, the cohesiveness of the products in the first week was similar at all three temperatures $\left(25^{\circ} \mathrm{C}, 35^{\circ} \mathrm{C}, 45^{\circ} \mathrm{C}\right)(\mathrm{p}>0.05)$. At all three temperatures, the cohesiveness increased up until 15 days of storage. At this point, the cohesion of the cupcakes at $25^{\circ} \mathrm{C}$ slightly decreased, while the cohesion at $35^{\circ} \mathrm{C}$ and $45^{\circ} \mathrm{C}$ increased at a higher rate.

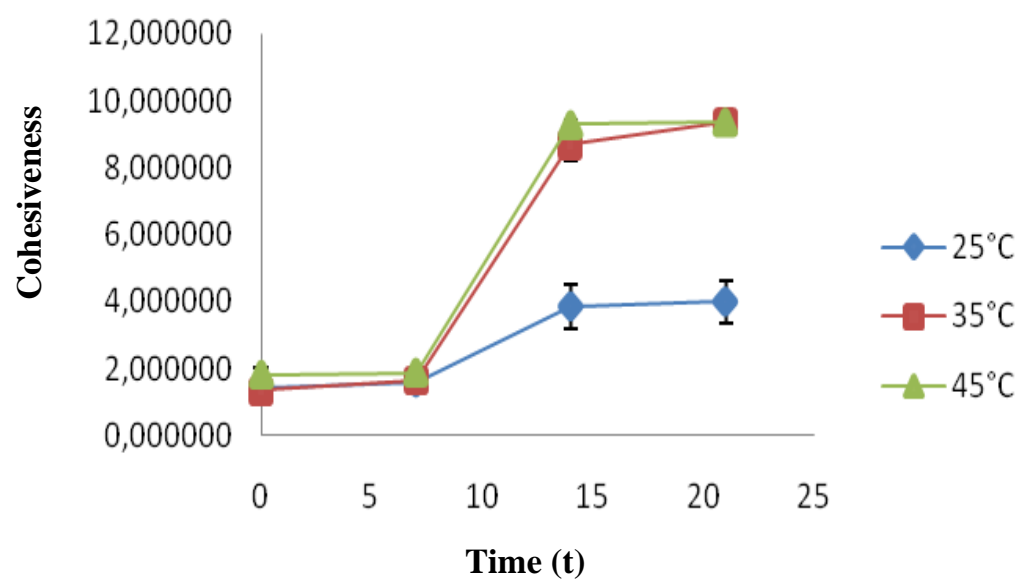

Figure 4. Variation of cohesion as a function of time and temperature.

\section{Gumminess during storage}

The gumminess of a product is calculated by multiplying the hardness and cohesiveness values of the given product. Therefore, increasing these two factors would increase the gumminess of a product.

As seen in Figure 5, the gumminess of the cupcakes was relatively low until days 8-9 of storage. At roughly 14 days, the gumminess of the cupcakes at $25^{\circ} \mathrm{C}$ remained relatively constant, while that of the cupcakes at $35^{\circ} \mathrm{C}$ and $45^{\circ} \mathrm{C}$ increased greatly $(\mathrm{p}<0.05)$. 


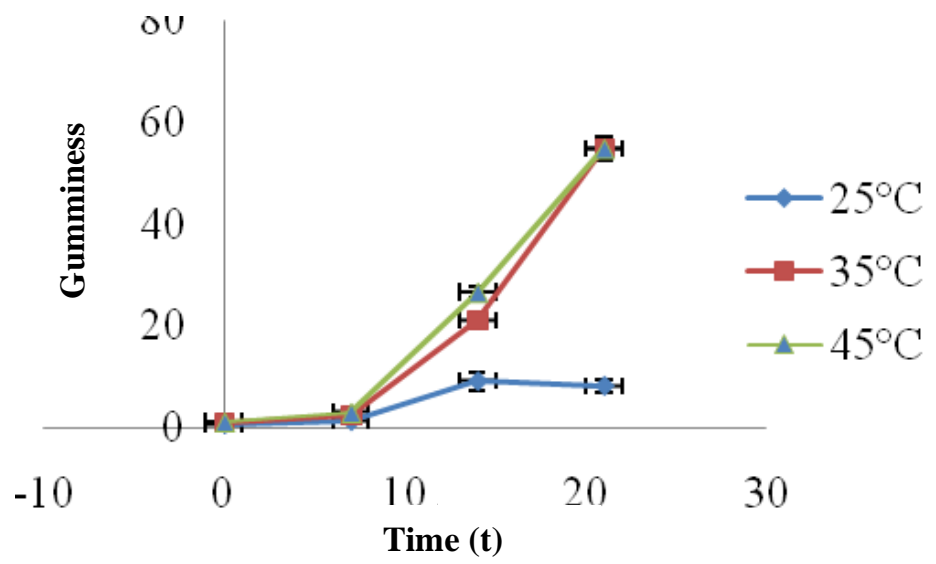

Figure 5. Variation of the gumminess as a function of time and temperature.

\section{Evaluation of adhesiveness during storage}

Adhesiveness is the degree to which a food sticks to a given surface. Products that contain hydrocolloids are generally more stable than gluten products when kneading. This is likely due to the high degree of internal cross-linking seen in hydrocolloids due to the formation of disulfide bridges. As a result of this viscoelastic network forming, it is probable that the adhesiveness of the cupcakes will be greater during the first weeks of storage [12].

As seen in Figure 6, the adhesiveness of the cupcakes progressively decreases over time at temperatures of $35^{\circ} \mathrm{C}$ and $45^{\circ} \mathrm{C}$, while it increases slightly and then decreases at $25^{\circ} \mathrm{C}$. It is also notable that at day 14 of storage, the adhesiveness of the samples at all three temperatures was the same ( $\mathrm{p}>0.05)$.

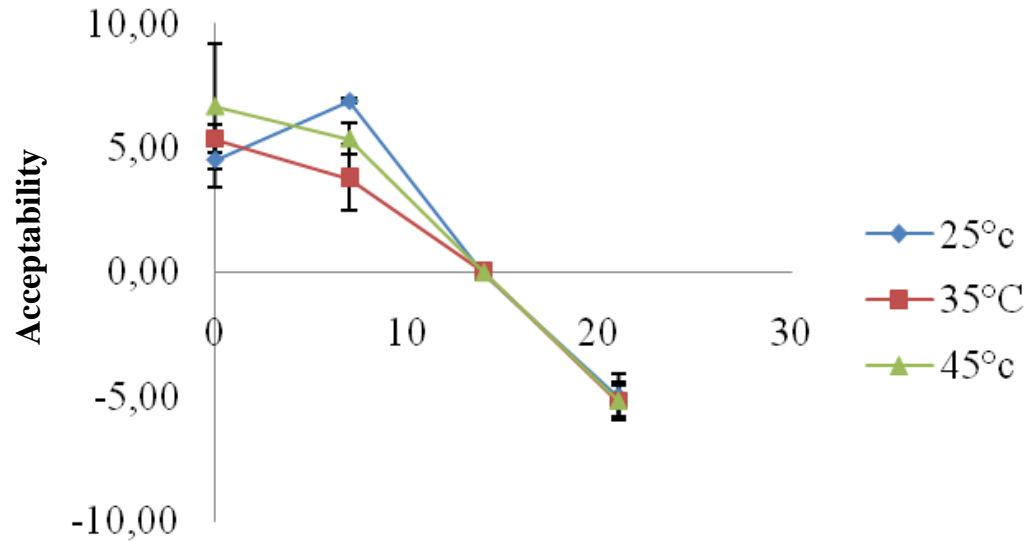

Time (t)

Figure 6. Variation of adhesiveness as a function of time and temperature.

\section{Acceptability during storage}

The acceptability of the cupcakes was examined during storage (Figure 7). For the first two weeks, the minimum value of 5.3 was seen at $45^{\circ} \mathrm{C}$ after 14 days, while the maximum of 7.5 was observed at $25^{\circ} \mathrm{C}$ when the storage test began. These two values correlate to "I am indifferent" and "I like 
moderately," respectively. However, after 21 days of storage, the minimum acceptability value dropped to 4.2 at a temperature of $45^{\circ} \mathrm{C}$, while the maximum value was 6.0 at $25{ }^{\circ} \mathrm{C}$. These two values correlate to "I dislike slightly and "I like slightly," respectively.

The level of intent to purchase the cupcakes was examined as well. During the first few days of storage, the maximum intent to purchase of $90 \%$ was seen in the cupcakes stored at $25{ }^{\circ} \mathrm{C}$, while the minimum of $85 \%$ was seen in the cupcakes at $45^{\circ} \mathrm{C}$. However, as the time of storage increased, the intention to purchase decreased. After 21 days of storage, the maximum intent to purchase was $63 \%$ for the cupcakes stored at $25{ }^{\circ} \mathrm{C}$, and the minimum was $49 \%$ for the cupcakes stored at 45 ${ }^{\circ} \mathrm{C}$.

The decrease of acceptability in the cupcakes can be attributed to the chemical deterioration of the baked products caused by hydrolytic and oxidative rancidity processes. These processes cause unpleasant odors and flavors, hence why the panelists disliked the products [18].

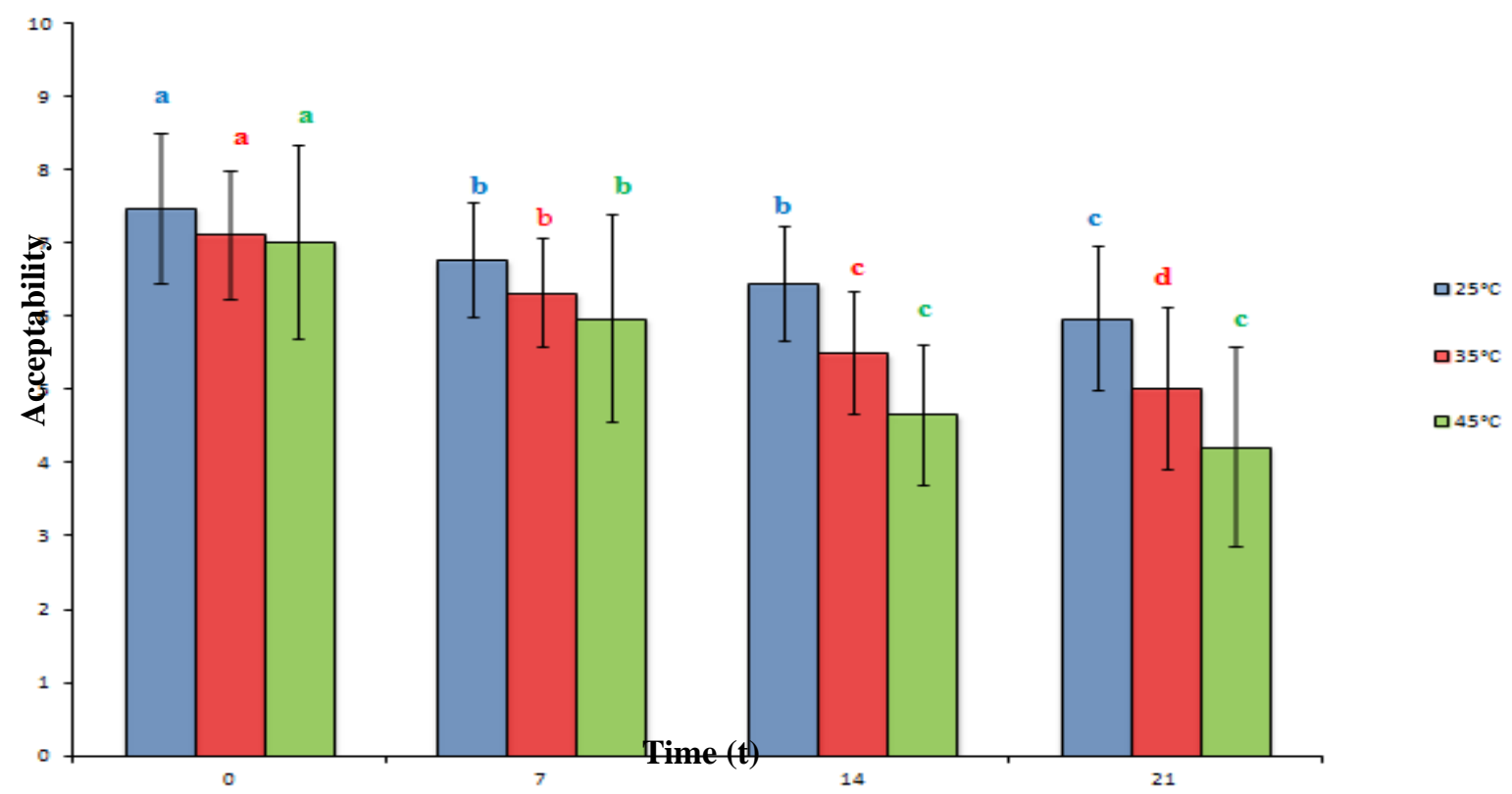

Figure 7. Acceptability of the cupcakes at three temperatures for 21 days.

Mean \pm standard deviation, $n=50$. Values with the same letter $(a, b, c, d)$ are not significantly different $(p>0.05)$.

\section{Estimation of shelf life}

To determine the shelf life at $28^{\circ} \mathrm{C}$, the average temperature in Venezuela [19], Log t vs. T $\left({ }^{\circ} \mathrm{C}\right)$ was plotted to obtain an equation of time as a function of temperature (Figure 8). It was found that at $28{ }^{\circ} \mathrm{C}$, the product can last 14 days without undergoing significant changes in hardness $\left(\mathrm{R}^{2}=\right.$ $0.83)$.

It is observed that there is an inverse relationship between temperature and the shelf life of the product. In the literature examined there was no standard shelf life of baked goods due to the fact that the hardness of a crumb varies according to the constituents, additives and temperature [20]. 


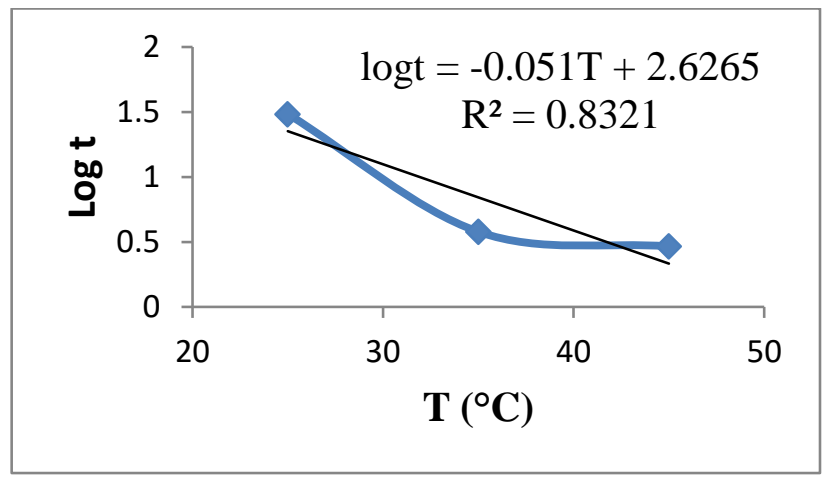

Figure 8. Determination of shelf life as a function of temperature.

\section{CONCLUSIONS}

A low-cost gluten-free formulation of a filled cupcake, with high acceptability, was selected. There was an inverse relationship between both time and temperature and the acceptability of the cupcakes as rated by possible consumers. In addition, the texture of the cupcakes deteriorated as time went on. Due to the processes of aging and rancidity, the product became tough, gummy, and less adhesive. Finally, the shelf life of the filled cupcake, when kept at the average temperature of Venezuela $\left(28^{\circ} \mathrm{C}\right)$, was 14 days.

List of Abbreviations: CD, celiac disease; GSE, gluten-sensitive enteropathy; GFB, gluten-free bread; GF, gluten-free; SV, specific volume; HPMC, hydroxy propyl methyl cellulose; CMC carboxymethyl cellulose; FCA, factorial correspondence Analysis.

Author Contributions: Jhoana Colina designed and conducted the research. Carolina Gómez performed chemical, physical, microbiological, sensory and statistical analyses. All authors read and approved the final version of the manuscript.

Competing Interests: There are no conflicts of interest to declare.

Acknowledgements and Funding: We are deeply grateful with the Fundacion Celiacos de Venezuela for the sensory analysis with celiac people, We thank A Torres, I bucema, A cova, H Herrera, Y Valero, (laboratory of food analysis, University Simon Bolivar) for their technical assistance during the study.

\section{REFERENCES}

1. Floros JD, Newsome R, Fisher W, Barbosa-Canovas G, Chen H, Dunne CP, German JB, et al.: Feeding the world today and tomorrow: The importance of food science and technology. ComprRev Food Sci Food Saf. 2010, 9: 572-599.

2. FAO. (Organización de las Naciones Unidas para la agricultura y la alimentación): El maíz en la nutrición humana. En Alimentación y Nutrición. Roma, Italia, Numero 25, 2008.85 . 
3. Ali I, Mariasch N, Maurel S, Deschutter S: Enfermedad celíaca: formas de presentación clínica en la población pediátrica. Revista de Posgrado de la Cátedra de Medicina, 2008,(157): 3-6.

4. Calvo C: Mesa redonda: enfermedad celíaca en el siglo XXI. Boletín de la sociedad de Pediatría de Asturias, Cantabria, Castilla y León, 2003,(4):309-312

5. Hozova B, Kukurova I, Turicova R, Dodok L: Sensory quality of stores croissant- type bakery products. Czech J Food Sci. 2002, 20(3):105-112.

6. Yassen E, Herald T, Aramouni F, Alavi S: Rheological properties of selected gum solutions. Food Res Int. 2005, 38:111-119.

7. AACC (American Association of Cereal Chemist). Cereal Laboratory Approved Methods. Volume 1-2 10 ${ }^{\text {th }}$ edition; 2000:133-350.

8. Garcia A, Lecheri D: Determinación de la vida útil en tres formulaciones de ponqué. Msc thesis. Universidad Simón Bolívar, Departamento de procesos biologicos y bioquímicos; 2013, 17-27.

9. COVENIN 1126. (Comisión Venezolana de Normas Industriales Alimentos). Identificación y Preparación de Muestras para el Análisis Microbiológico. FONDONORMA. Venezuela; 1989.

10. Eliasson AC: On the effects of surface active agents on the gelatinization of starch a calorimetric investigation. Carbohydrate Polymers 1986, (6), 463-476.

11. Villagra, Anabel: Almidón retrogradado en el tratamiento dietoterápico de la Diabetes Mellitus tipo 2. Tesis en Licenciatura de nutrición Universidad ISALUD; 2010.

12. Riemsdijk L, Goot A, Hamer R, Boom R: Preparation of gluten free bread using a mesostructured whey protein particle system. Journal of Cereal Los Hongos de los Alimentos y Forrajes. Science 2011, 53:355-361.

13. Lopez, L, Dyner, L, Vidueiros, S, Pallaro, A, Valencia, M: Determinación del contenido de gliadinas en alimentos elaborados con amaranto, quínoa y/o chía. Revista Chilena de Nutrición, 2010, 37(1): 80-86.

14. Carrillo. L: PHD Thesis. Universidad Nacional de Salta 2003, 94-118

15. Gélinas P, Roy G, Guillet M: Relative effects of ingredients on cake staling based on an accelerated shelf-live test. Journal of Food Science 1999, 64 (5): 937-940.16.

16. Galic K, Curic D,Gabric, D: Shelf Life of Packaged Bakery Goods. Food Science and Nutrition, 2009,405-426.

17. Maldonado S, Singh Y: Efecto de la formulación de dulce de yacón. Food Science and Technology. Ciencia Tecnologia de alimentos, 2018.

18. Smith J, Phillips D, El-Khoury W, Koukoutsis J, El-Khoury A: Shelf Life and Safety Concerns of Bakery Products - A Review. Critical Reviews in Food Science and Nutrition 2010, 44:1,19-55

19. Torres A, Guerra M, Rosquete Y: Estimación de la vida útil de una formula dietética en función de la disminución de lisina disponible. Ciênc Tecnol Aliment, Campinas. 2001, $21(2), 129-133$.

20. Labuza T: Shelf-life dating of foods: Food \& Nutrition Press, Inc, 1982. 233 - 243. 